\title{
Antitrust, Foreign Policy, and International Buying Cooperation
}

\author{
Joel Davidow ${ }^{\dagger}$
}

There has been considerable debate in the last few years over whether the antitrust laws of the United States unduly disadvantage American businessmen in international trade situations. ${ }^{1}$ Recent events indicate that, despite continuing concern about export promotion, the most crucial foreign trade problems for our nation in the near future will likely arise on the buying rather than the selling side.

Traditionally, most countries have policies, including antitrust exemptions, designed to encourage exports. ${ }^{3}$ Such programs have usually been based on the assumption that an excess of exports over imports is a "favorable" balance of trade, since the nation thus becomes a creditor rather than a debtor in monetary terms. ${ }^{4}$ Our position as

$\dagger$ Chief, Foreign Commerce Section, Antitrust Division, U.S. Department of Justice. The views expressed are entirely personal and are not intended as expressions of the official position of any governmental agency.

1. See, e.g., Hearings on International Aspects of Antitrust Before the Subcomm. on Antitrust and Monopoly of the Senate Comm. on the Judiciary, 93d Cong., 2d Sess. (1974).

2. See generally Bergsten, The Threat is Real, FoneIGN PoLICY, Spring 1974, at 84; Bergsten, The Threat from the Third World, ForeIGN Policx, Summer 1973, at 102; Krasner, Oil Is the Exception, ForeIGN Policy, Spring 1974, at 68; Mikdashi, Collusion Could Work, ForeIgN PoLICY, Spring 1974, at 57; Symposium, One Too Many OPEC's, ForeIgN Policy, Spring 1974, at 57-99.

3. Most United States programs to encourage exports are handled under the auspices of the Office of Export Promotion within the Department of Commerce. This office offers advice, guidance and limited forms of assistance to would-be exporters. Exports are also promoted through tax incentives. See INT. REv. CoDE of 1954, \$ 994(c). For a number of years exports were indirectly encouraged by laws and regulations limiting the amount of direct American foreign investment. This was administered by the Office of Foreign Direct Investment Control in the Department of Commerce.

On the antitrust side, the major device to encourage exports is the Webb-Pomerene Export Trade Act of 1918,15 U.S.C. $\$ \$ 61-65$ (1970), which requires a group of firms associated for the sole purpose of export trade to register with the Federal Trade Commission (FTC). The export activities of such associations are expressly exempted from the antitrust laws, provided that the agreements and acts of the association do not restrain trade within the United States, artificially enhance or depress prices within the United States, or restrain the export trade of any domestic competitor of the association. See generally Chapman, Exports and Antitrust: Must Competition Stop at the IVater's Edge?, 6 Vand. J. Transnat'L L. 399 (1973).

4 . On the other hand, most economists agree that the balance of trade is theoretically self-correcting, P.B. KENEN \& R. LUBITZ, INTERNATIONAL Economics 57-78 (3d ed. 1964); C.P. Kindleberger, International Economics 38-54 (4th ed. 1958); P. Samuelson, EcoNomics 625 (8th ed. 1970), and many argue that goods are the only real wealth. Under this theory, a nation should seek a surplus of imports, since it will thus actually be "richer" than a nation with a surplus of gold or currency. See B.J. MOORE, AN INTRODUCTION TO MODERN ECONOMIG THEORY 492-93 (1973); P. SAMUeLSON, supra, at 621-39. 
an exporter has recently been greatly improved by the hard but necessary step of devaluation of our currency. That measure, combined with others of less significance, resulted in a "positive" balance of payments for a few months, ${ }^{5}$ and might do so again if our problems as a consumer nation can be controlled.

As a buyer, we are faced with increasing dependence on imported commodities. World commodity shortages, major competition from Europe and Japan for scarce resources, and state monopolies and concerted producer cartels have forced us to pay much higher prices for many commodities. ${ }^{\circ}$ Suggested solutions to our problem as a buyer of scarce or monopolized goods have included retaliative boycotts, $^{7}$ collective buying and bargaining groups, ${ }^{8}$ government intervention in purchasing, ${ }^{9}$ and even collaboration with other purchasing governments. ${ }^{10} \mathrm{~A}$ number of these suggestions raise important issues concerning how our antitrust laws should be interpreted, and even whether they should be altered. We should recognize that even government joint action raises implicit questions of antitrust policy, broadly viewed. The basis of our antitrust laws is a dedication to the ideal of free markets at home and abroad, in which numerous private buyers and sellers transact business without resort to cartels or boycotts. However, in the midst of international economic warfare-whether conducted by corporations with government sanction or by governments themselves-the underpinning of the antitrust laws may be abandoned, and progress toward free and open world markets could be stifled in the name of national advantage.

The primary purpose of this article is to analyze American antitrust law and policy as it applies to international buying groups. To

5. See, e.g., Wall St. J., Nov. 28, 1973, at 5, col. 3; May 28, 1974, at 2, col. 2; Oct. 18,1974 , at 3 , col. 3 .

6. See, e.g., OPEC for Oil; CIPEC for Copper: What Next-A BAUPEC for Bauxite?, ForBEs, Feb. 15, 1974, at 49; Cartel Phobia, NEW'WEEk, Jan. 28, 1974, at 60; OPEC Moves to Check Consumer Cartel, OIL \&: GAS J., Mar. 26, 1973, at 42; New Export Cartel: Union of Banana Exporting Countries, Time, Apr. 29, 1974, at 94; Nations with Raw Materials - Can They Gang UD on U.S.?, U.S. NEWS \& WORLD REP., May 6, 1974, at 76-77.

7. E.g., H.R. 13840 \& S.3282, 93d Cong., 2d Sess. (1974) (proposed amendments to the Export Administration Act submitted by the Dep't of Commerce authorizing the President, inter alia, to impose export controls in order to retaliate against nations that unreasonably restrict U.S. access to a commodity). See Landauer, Crude Tactics: How the State Department Helped Big Oil Firms Try to Thwart Libya, Wall St. J., Feb. 15, 1974, at 1 , col. 1 .

8. Some 19 Farm Co-Ops Form Trading Group to Buy Foreign Fuel, Wall St. J., Mar. 14,1974 , at 25 , col. 6 .

9. Senator Church has advocated legislation to this effect. See N.Y. Times, June 6, 1974, at 1, col. 1 .

10. At the height of the energy crisis caused in part by the Arab boycott, the U.S. Department of State moved in this direction. 70 DEP'T STATE BULL. 201-22 (1974); OPEC Moves to Check Consumer Cartel, OrL \&: GAS J., Mar. 26, 1973, at 42. 
do this, we must first decide whether the antitrust laws as applied to domestic commerce allow competitive or potentially competitive companies to engage in cooperative or joint buying. If under some circumstances such conduct is unlawful, it must then be determined whether a different conclusion results when the buying group operates abroad in purchasing from foreign sellers. We shall next consider whether the answer to this latter question depends on the fact that the buyers are confronted with a foreign monopoly or cartel, or are bargaining with a foreign state about taxes or royalties rather than with private sellers about the price of foreign goods. Assuming that international buying groups are legal in some situations, the antitrust laws are examined to assess what conditions are imposed on access to or membership in such groups, on the bargaining independence of those in the group, and on the scope of agreements or activities of the group. Finally, this article focuses on the proper role of the United States government in relation to international buying groups and, in particular, whether the government should only define the rules for the existence of these groups or whether it should instead concern itself with the substance of their negotiating. positions.

\section{The Antitrust Legality of Domestic Buying Groups}

It seems undeniable that virtually any buying group involves some restraint on competition among buyers. If, for instance, potential buyers of a product appoint one or more of their number as negotiators and instruct them as to what price, or range of prices, to offer or accept, the members to that extent restrict their own freedom to bid separately or on differing terms for the commodity being purchased. ${ }^{11}$ Further, if the buyers authorize their negotiator to refuse to deal if the price is not as low as they wish, they have implicitly threatened the seller with a boycott, which is a restraint normally condemned as illegal per se under $\$ 1$ of the Sherman Act. ${ }^{12}$

In fact, it has been long settled that the Sherman Act ban on conspiracies in restraint of trade prohibits concerted buying by a group with market power. The courts will not accept the defense that such

11. See United States v. Socony-Vacuum Oil Co., 310 U.S. 150 (1940); Blue Cross v. Commonwealth, 211 Va. 180, 176 S.E.2d 439 (1970); cf. United States v. United States Alkali Export Ass'n, 86 F. Supp. 59 (S.D.N.Y. 1949).

12. Klors, Inc. v. Broadway Hale Stores, Inc., 359 U.S. 207 (1959); Associated Press v. United States, 326 U.S. 1 (1945); Fashion Originators Guild v. FFC, 312 U.S. 457 (1941); Boyle v. United States, 40 F.2d 49 (7th Cir. 1930). 
joint buying might produce a lower price for the consumer. As early as 1905 the Supreme Court condemned an agreement among leading meatpackers pursuant to which, among other things, they refrained from bidding against each other for livestock. ${ }^{13}$

Other cases have reached the same conclusion. In Live Poultry Dealers Protective Association v. United States, ${ }^{14}$ the Government sought to prohibit an arrangement under which many of the poultry buyers in New York appointed a negotiating committee authorized to bid for poultry to obtain a "market price," which would usually then be the price on all transactions during that day. The parties agreed that prior to this plan "the prices for live poultry had been determined without any rule and according to the higgling of the buyers and the sellers." 15 Defendants attempted to justify their plan as reasonable, arguing that an unstabilized market "resulted in frauds upon the buyers and in the end a higher price to the consumers."16 In rejecting this defense, Judge Learned Hand stated that:

$[I] t$ is somewhat surprising at this day to hear it suggested that a frank agreement to fix prices and prevent competition as regards them among one-half the buyers in a given market may be defended, on the notion that the results are economically desirable. We should have supposed that, if one thing were definitely settled, it was that the Sherman Act forbade all agreements preventing competition in price among a group of buyers, otherwise competitive, if they are numerous enough to affect the market. ${ }^{17}$

Mandeville Island Farms, Inc. v. American Crystal Sugar Co..8 involved a monopolistic buying group that was charged with violating $\$ \$ 1$ and 2 of the Sherman Act. Three large sugar refiners in northern California agreed to pay uniform prices for sugar beets. These refiners were the only practical market for beets grown in northern California. The Supreme Court held that the price-fixing agreement by purchasers was a Sherman Act violation, but did not specifically rule that the buying group itself was illegal. ${ }^{19}$

13. Swift \& Co. v. United States, 196 U.S. 375 (1905). For a more recent case involving concerted buying. see United States v. Intercontincntal Fur Corp.,. Criminal No. 68 CR 701 (S.D.N.Y. 1969). The indictment alleged that defendants agreed to allocate lots of sealskins on which they would bid or refrain from bidding against each other. Each defendant pleaded nolo contendere and was fined.

14. 4 F.2d 840 (2d Cir. 1924).

15. Id. at 841 .

16. Id.

17. Id. at 842 .

18. 334 U.S. 219 (1948).

19. Id. at 227 . 
In National Macaroni Manufacturing Association v. FTC, ${ }^{20}$ the complaint charged an association of macaroni manufacturers with acting collectively to suppress competition. These manufacturers accounted for 70 percent of United States macaroni production. The association fixed the ingredients of the macaroni in order to reduce the demand for, and hence the price of, durum wheat. The Ninth Circuit affirmed the FTC's finding of a per se violation of $\$ 5$ of the Federal Trade Commission Act. However, the court went on to state:

It seems appropriate to note here that in the instant case the Commission did not hold that all efforts at product standardization, or all buying agencies or other cooperative buying arrangements, or all attempts to cope with scarcity or other conditions of economic dislocation are unlawful under the antitrust laws. ${ }^{21}$

As the court of appeals noted in National Macaroni, it is well known that many forms of joint buying groups do exist, even in the domestic economy, and generally are not challenged under the antitrust laws. On occasion, particular joint buying arrangements have been held legal by the courts or granted clearances by antitrust enforcement agencies. Examples include small theater owners jointly purchasing films, small grocers purchasing foodstuffs in bulk, and greeting card buyers using a buying corporation. ${ }^{22}$ In the case involving joint buying by greeting card distributors, the Examiner and the FTC, in approving the plan, stressed that its members accounted together for only $\$ 3$ million out of $\$ 250$ million sales in the industry. ${ }^{23}$

There appear to be two reasons for this exception to the general condemnation of conspiracies and combinations. First, the members are able to achieve joint economies of purchasing scale that they could not obtain alone, and thus enhance their ability to compete with larger buyers in the market. In addition, because the participants are so small and insignificant in terms of market share that a complete merger of their facilities would be unobjectionable un-

20. 345 F.2d 421 (9th Cir. 1965).

21. Id. at 427 .

22. Central Retailer-Owned Groceries, Inc. v. FTC, 319 F.2d 410 (7th Cir. 1963) (small grocers); Arkansas Brokerage Co. v. Dunn \& Powell, Inc., 173 F. 899 (8th Cir. 1909) (mercantile jobbers); G \& P Amusement Co. v. Regent Theatre Co., 107 F. Supp. 453 (N.D. Ohio 1952), aff'd, 216 F.2d 749 (6th Cir. 1954) (theatres); Mid-West Theatres Co. v. Co-Operative Theatres, Inc., 43 F. Supp. 216 (E.D. Mich. 1941) (theatres); Associated Greeting Card Distrib., 50 F.T.C. 631 (1954).

23. 50 F.T.C. at 631, 633, 634 . 
der the antitrust laws, there can be no objection to their engaging in joint purchasing, a form of integration which falls short of merger or consolidation. ${ }^{24}$

The legality of domestic buying groups is governed not only by the Sherman Act but also by $\$ \S 2(c), 2(e)$ and 2(f) of the RobinsonPatman Act. ${ }^{25}$ These provisions are aimed at preventing a powerful buyer (single or group) from receiving or inducing discounts or allowances not available on equal terms to smaller buyers or justified by cost saving resulting from the quantity purchased or method of purchasing. Thus, in a sense the antitrust and price-discrimination laws prohibit not only the methods of powerful buying groups, but also their achievements. Still, many buying groups or cooperatives do pass muster under the Robinson-Patman Act. The rationale for this is that small retailers should be able to combine in order to equal large commercial chains in buying power and efficiency. ${ }^{26}$

It appears from this discussion that one can formulate an approximate rule governing the legality of joint domestic buying arrangements: If the joint buying arrangement is necessary to achieve genuine economies of scale that are important and not attainable by the members acting separately, and if the joint purchasing group as a whole does not account for an economically significant percentage of the commodity or service being purchased, ${ }^{2 \pi}$ then such a group should be generally unobjectionable under the antitrust laws. ${ }^{28}$ While many

24. See Kintner, Romano \& Filippin, Cooperative Buying and Antitrust Policy: The Search for Competitive Equality, 41 GEo. WAsH. L. REV. 971 (1973); Mezines, Group Buying: When Is It Permitted Under the Robinson-Patman Act?, 44 N.Y.U.L. REv. 729 (1969).

25. 15 U.S.C. $\S 13(c)$, (e), (f) (1970).

26. Central Retailer-Owned Grocers, Inc. v. FTC, 319 F.2d 140 (7th Cir. 1963). FTC Chairman Paul R. Dixon stated:

- [C]ombination in one form or another by small firms may be essential to their survival, particularly in those industries characterized by massive aggregates of corporate power. The growth of the giant food chains, for example, revolutionized the behavior of small independent grocery stores. They were quickly faced with the alternative of constructing cooperative buying arrangements or extermination. Certainly many independent food stores long ago would have withered before the competitive threat of large chains had they not formed retailer-owned cooperative wholesalers....

Address before the Economic Club of Detroit, Mar. 12, 1962, quoted in 319 F.2d at 415 , and in National Retailer-Owned Grocers, Inc., 60 F.T.C. 1208, 1247 (1962) (dissenting opinion).

27. Perhaps 10 percent of the market would be such an "economically significant" market share; cf. Brown Shoe Co. v. United States, 370 U.S. 294 (1962); Standard Oil Co. v. United States, 337 U.S. 293 (1949) (Standard Stations case).

28. See C. Kaysen \& D. TuRner, Antitrust Policy 153 (1959):

[I] $n$ the absence of evidence of intent to reduce price competition or of actual effects on price that are unrelated to cost savings the test would be whether...the joint buying agency has the power to depress prices by withholding demand..... If the exclusive joint agency is found to possess such power, it would be held illegal in the absence of a clear showing that there are substantial economies which cannot be achieved by a nonexclusive agency or by independent firms. 
buying groups would be acceptable, this test would certainly not permit the leading firms in an industry to join together.

\section{The Relevance of the International Context}

The preceding section indicates that, even in the international context, American antitrust law would probably not prohibit or punish buying groups which both lack market power and are reasonably necessary to achieve economic efficiency. The harder questions arise when the proposed international buying group clearly does possess significant market power because its members include the largest firms in the American market or a high percentage of all firms in that market. The issue is highlighted when the American buying syndicate is defended precisely because it will enable its members to exact lower prices from the foreign sellers than would be obtainable if the foreigners could play one American buyer off against another. There can be little doubt that a domestic buying group with such power would be illegal under the Sherman Act, and that the defense of obtaining lower prices or stabilizing the market would be rejected, as it was in Live Poultry Dealers.

The primary theoretical justification for the legality of American buying groups operating abroad would be that America lacks legislative jurisdiction to protect foreigners from anticompetitive practices; or that, even if Congress possesses such power, it had no intent to bestow the benefits of Sherman Act protection on foreigners. Put another way, the reasoning is that since the only victims of such a conspiracy would be foreigners, since a probable result of the joint action would be higher profits for American companies, and since cost savings might be passed on through lower prices for American consumers, the Sherman Act should not be interpreted to prohibit such an agreement.

Experts in the field appear to disagree on whether the Sherman Act proscribes a conspiracy among Americans in United States foreign commerce which injures only foreigners. Kingman Brewster concluded in 1958 that the Sherman Act probably would not and should not apply in such circumstances:

A restraint which on its face only governs activity within or among foreign nations would seem prima facie outside the legislative jurisdiction. Even a naked restraint on foreign local or "thirdmarket" commerce would seem subject to liability if, and only if, the government could prove the effect on competition in United States domestic or foreign commerce. ${ }^{20}$

29. K. Brewster, JR., ANTtrRust and AMmerican Business Abroad 82 (1958). 
Dean Rahl, relying on a more literal reading of the statute, recently offered a somewhat broader interpretation of the Sherman Act:

But it may be said, if the restraint does not hurt U.S. commerce, or if it actually helps it, why should the Act apply? Foreign trade and foreign markets, it is argued, should be viewed differently from domestic problems-in our own self-interest, and because it is not the business of Congress to concern itself with restraints inflicted by Americans upon foreigners abroad. One answer might be the direct one that it would not be so strange for Congress to be concerned with what our businesses do to foreigners. If we are concerned with warfare and crime carried on by Americans abroad, we might reasonably be concerned with the infliction of economic damage abroad by conduct considered illegal at home.

But that answer might still miss the point. Personally, I would stick to what I consider to be the only reliable guide to the scope of the Act-that is, that the Act is concerned with restraints of competition which occur in, or which substantially affect any of the commerce, interstate or foreign, which Congress regulates. ${ }^{30}$

In support of Rahl's view, it can be said that well-settled principles of international and American constitutional law would certainly allow Congress to forbid joint activities by Americans which injure foreigners abroad. ${ }^{31}$ One ground for such legislative reach would be the adverse effect which such conspiracies might have on American foreign trade and foreign policy. ${ }^{32}$ If we permitted our businessmen to combine against foreign sellers, the foreigners or their governments might retaliate in ways injurious to other American businessmen, to American foreign trade or to American foreign relations. It is certainly possible that foreign sellers, faced with a powerful buying

30. Address by Rahl, American Antitrust and Foreign Operations: What Is Covered?, at 9, Northwestern Univ. Law School Corporate Counsel Institute, Oct. 3, 1973.

31. See Blackmer v. United States, 284 U.S. 421 (1931). This casc involved the constitutionality of a federal statute providing for personal service of subpoenas on American citizens residing in a foreign country. The Court held that Congress had legislative power to apply U.S. law to acts of American citizens done outside the territorial jurisdiction of the United States. Id. at 436-38. In Branch v. FTC, 141 F.2d 31 (7th Cir. 1944), petitioner was charged under $\$ 5$ of the Federal Trade Commission $\Lambda$ ct with unfair business practices in the operation of a correspondence school distributing correspondence courses by mail to Latin America. In upholding jurisdiction over his activities the court stated:

The right of the United States to control the conduct of its citizens in foreign countries in respect to matters which a sovereign ordinarily governs within its own territory has been recognized repeatedly [citing Blackmer v. United States, supra]. Congress has the power to prevent unfair trade practices in foreign commerce by citizens of the United States, although some of the acts are done outside the territorial limits of the United States.

141 F.2d at 35. See generally United States v. Timken Roller Bearing Co., 341 U.S. 593 (1951).

32. See Perez v. Brownell, 356 U.S. 44, 57-60 (1958); Ramey v. United States, 230 F.2d 171 (5th Cir. 1956); cf. Friend v. United States, 100 F.2d 691, 693 (D.C. Cir. 1938). 
group, might well choose to respond by forming some sort of selling group or export cartel, or by requesting that their government become their sales agent. Most trading nations are quite permissive or even encouraging about the formation of export cartels, so this result would not be at all unlikely. Since the Sherman Act by its terms applies to all conspiracies which restrain American foreign commerce, there is a great deal of appeal to Rahl's argument that once it is proved that American foreign commerce is being collusively restrained, the identity of the direct or indirect victims is irrelevant. ${ }^{33}$

Moreover, it is not at all certain that a conspiracy to obtain lower prices from foreign sellers cannot itself injure American businessmen or consumers. For instance, if there are American sellers of the product which is jointly purchased abroad at prices below normal market value, the effect of the joint purchasing on the American competitors could be approximately the same as if the foreign product had been "dumped" on the American market at less than fair value. Thus, the American sellers might be prevented from competing effectively by a conspiracy of American buyers to purchase abroad. In addition, if the product is not available in the United States, or is in short supply, the joint purchasers might be able to retain the entire amount attributable to their bargaining strength as "excess" profits; such control over the product might entrench the dominant position of these firms, thereby discouraging potential entrants into the field..$^{34}$ It could still be argued that the effect of the joint purchasing was to increase the profits of American firms at the expense of foreigners, but there would be no truth to the argument that the joint purchasing produced any benefit for ultimate consumers in America. There is also the danger that higher rather than lower prices would result. Of course, it can be assumed that American antitrust law would absolutely prohibit joint purchasers from agreeing to the resale price in America. ${ }^{35}$ But uniform, supracompetitive prices might emerge anyway as a result of identical costs of purchase and the individually perceived common interest,

33. See Todhunter Mitchell \& Co. v. Anheuser-Busch, Inc., 43 U.S.L.W. 2190 (E.D. Pa., Oct. 11, 1974) (relief available to dealer cut off in British Bahamas); Kuwait v. Chas. Pfizer \& Co., 333 F. Supp. 315 (S.D.N.Y. 1972) (Kuwait in "person" entitled to damages if overcharged in U.S. foreign commerce).

34. Cases construing the Clayton Act merger provision indicate that competition by a potential entrant into the field is relevant. See Procter \& Gamble Co. v. FTC, 386 U.S. 568 (1967).

35. United States v. Timken Roller Bearing Co., 341 U.S. 593 (1951); United States v. Aluminum Co. of America, 148 F.2d 416,443 (2d Cir. 1945). 
especially if the joint purchasing group was oligopolistic in nature, i.e., dominated by a few large members. Finally, as a legal matter, it should be recalled that American antitrust law strictly applied condemns agreements to lower prices as well as to raise them. ${ }^{36}$

Another concern about competitor cooperation in an international selling or buying group composed of the major firms in the domestic market is that contact and mutual aid among formerly competing firms may eventually encourage or facilitate collusion to limit domestic competition. Although it would be illegal for American firms to employ joint international bargaining as a disguise for a scheme to eliminate domestic competition, ${ }^{37}$ only the naive could deny the possibility that the existence of frequent opportunities for private business discussions may ultimately result in such collusion. Longstanding and substantial cooperation in international dealings very well may dull the appetite for fierce rivalry at home. Judge $\mathrm{Wy}$ zanski voiced a similar concern in narrowly construing the WebbPomerene Act exemption to the antitrust laws for joint foreign selling groups:

The intimate association of the principal American producers in day-to-day manufacturing operations, their exchange of patent licenses and industrial know-how, and their common experience in marketing and fixing prices may inevitably reduce their zeal for competition inter sese in the American market .... ${ }^{38}$

Certainly, international buying groups raise this same problem of creating opportunities for collusion affecting domestic purchasers. First, such buying groups tend to create identical costs for firms who will resell in the United States, which provides a convenient basis for setting identical prices. Second, there is simply the suspicion that "familiarity breeds attempt."

Unlike Webb-Pomerene export associations, buying groups do not have to register their existence or submit reports to federal authorities. It is possible that if a buying group sought a business review letter from the Justice Department or an advisory opinion from the FTC, such clearance would be conditioned upon assurances that the members of the group would not discuss resale prices for sale to American

36. Albrecht v. The Herald Co., 390 U.S. 1018 (1968); Kiefer-Stewart \& Co. v. Jos. Seagram \& Sons, Inc., 340 U.S. 211 (1951).

37. United States v. Sisal Sales Corp., 274 U.S. 268 (1927); United States v. American Tobacco Co., 221 U.S. 106 (1911).

38. United States v. Minnesota Mining \& Mfg. Co., 92 F. Supp. 947, 963 (D. Mass. 1950 ). 
or domestic competitive issues, and upon documentation that such discussions were not occurring and would be prevented. ${ }^{39}$ However, given the present state of the law, it seems very possible that firms will choose to form and operate international buying groups without seeking clearance from federal antitrust agencies or making any public announcement of either the group's existence or the manner in which it will operate.

On the basis of the foregoing analysis it seems reasonable to conclude that there are grave doubts about the legal correctness and the wisdom of declining to prosecute American buying groups with monopolistic buying power which purchase from foreign sellers who lack monopoly power.

\section{International Buying Groups and Foreign Monopolists}

\section{A. The Countervailing Power Rationale}

The most persuasive case for staying the application of our antitrust laws to joint international buying groups is presented when the American buyers demonstrate that they must deal with a foreign monopolist, either private or governmental, or with a foreign cartel that has monopolistic power. In these circumstances, the American buyers may argue not that their combined strength will exact an unusually low price from the foreign monopolist or cartel, but rather that joint action may better enable the American firms to bargain for a reasonable price and resist being charged a supracompetitive rate which would probably have to be passed on to consumers in the United States.

Speaking directly to this issue, Deputy Assistant Attorney General for Antitrust Donald I. Baker stated recently:

[S]ome would . . . argue that antitrust prevents American firms from operating effectively in the presence of foreign government cartels. I do not think this argument will stand up to careful analysis.

In fact, the Justice Department has authorized-and the Sherman Act permits-necessary cooperation among American firms to deal with a foreign government buying or selling cartel, provided that cooperation does not spill over into the domestic market. ${ }^{40}$

39. For registration of Webb-Pomerene export associations, see 15 U.S.C. $\$ 65$ (1970); Chapman, supra note 3, at 409 . For a discussion of review by the Justice Department, see C. KAYSEN \& D. TURNER, supra note 28, at 246. For the regulations governing FTC advisory opinions, see 16 C.F.R. $\$ 1.1$ (1974).

40. Address by Baker at UCLA, Mercantilism and Monopoly-The Alternative To A Competitive America, at 16-17, Nov. 16, 1973. 
Undoubtedly, one of the events on which these comments were based was the Antitrust Division's Business Review Clearance in 1971 for joint oil company bargaining and cooperation in response to collective demands for higher payments by the Organization of Petroleum Exporting Countries (OPEC). ${ }^{41}$ In regard to that event, Senator Proxmire wrote to Assistant Attorney General McLaren inquiring whether the Division had granted the companies an "exemption" from the antitrust laws and whether concerted action by the companies was consistent with the 1968 consent decree ending the Oil Cartel case.42 McLaren replied by stressing, "The Department of Justice does not have power to grant immunity to anyone for a violation of the antitrust laws or for a violation of a court decree. What we can do is state our present enforcement intentions based on representations that are made to us as to a course of conduct proposed to be undertaken." 43 Turning to an analysis of the merits of the oil companies' conduct, McLaren wrote:

The reported activities of the companies involve a joint effort on the part of both large and small to assure that the concerted approach of the producing countries will not work to the greater prejudice of some competitors-especially the smaller ones-than to others. Faced with this combination of oil producing countries, demanding higher fees in the form of taxes or royalties, the companies' actions of which we are aware represent no more than a countervailing force to minimize the adverse price effects on consumers. ${ }^{44}$

A theory of countervailing power as a justification for approval of joint buying groups with market power has been only implicitly recognized in American antitrust law in cases allowing joint employer bargaining against labor unions. ${ }^{45}$ While this rationale would not validate domestic buying groups, ${ }^{46}$ it might justify buying groups in an international situation. The relevance of that difference is that

41. N.Y. Times, Jan. 21, 1971, at 11, col. 4; BNA 1971 ANTitrust \& Trade Reg. Rep. No. 496 , at $A-1$.

42. See United States v. Standard Oil Co. (N.J.), 1969 Trade Cas. \ 72,742, at 86,647-48 (\$ V(C)) (S.D.N.Y. 1968).

43. Letter from Richard McLaren, Chief of the Antitrust Division, to Sen. Proxmire, Mar. 5, 1971, discussed in Borowitz, Joint Business Actions by Competitors: Are Any Permissible?, 32 OHIo St. L.J. 683, 686-87 (1971); Foreign CoMmerce ANd THE ANTItrust Laws 454-55 (W. Fugate ed. 1973).

44. Id.

45. NLRB v. Local 449, Truck Drivers, 353 U.S. 87 (1957); Air Line Pilots Ass'n Int'I v. CAB, 502 F.2d 453 (D.C. Cir. 1974); Clung v. Publishers Ass'n, 214 F. Supp. 520 (S.D. N.Y.), aff'd per curiam, 314 F.2d 343 (2d Cir. 1963); cf. NLRB v. Brown, 380 U.S. 278 (1965); Kennedy v. Long Island R.R., 211 F. Supp. 478 (S.D.N.Y. 1962), aff'd, 319 F.2d 366 (2d Cir.), cert. denied, 375 U.S. 830 (1963) (strike insurance).

46. Cf. C. KAYSEN \& D. TURNER, supra note 28 , at 153. 
in a domestic situation, one could reasonably rely upon application of the antitrust laws to remedy any selling cartel or monopoly with which buyers were faced. In an international context, our antitrust laws would be totally ineffective against a foreign cartel or monopoly, particularly if it were governmentally inspired or managed. Thus, the countervailing power justification appears to be more persuasive as a rationale for allowing international buying groups than domestic ones. ${ }^{47}$

On the other hand, absent substantive government participation or control, it is doubtful that allowing or encouraging joint bargaining by private, profitmaking firms is likely to secure significant benefits for American consumers. It appears that merely allowing such joint activity cannot guarantee that the group will achieve better results than if separate bargaining took place. Nor is it easy to ensure that negotiations between the companies and the cartel will be adversarial and arm's-length, and that any saving attained will be substantially passed on to American consumers.

First, bargaining results may be more closely related to the strength of the cartel, the scarcity of the commodity, and the availability of substitute products than to the number of buying corporations negotiating as a unit. Moreover, it is not clear that corporate selfinterest guarantees that firms will always negotiate jointly for the lowest possible price when economic circumstances will allow them instead to cooperate with the foreign sellers and pass on increases to consumers in America. Assuming that the foreign monopoly or cartel picks the American buyers with which it will deal, and that supply and demand characteristics are such that the joint buyers can easily pass on price increases to the ultimate consumers, it seems problematical whether the joint buying group will negotiate vigorously for the lowest possible prices and will not instead make a "sweetheart deal" with a foreign cartel at least to split the profits on resale in the United States. In a scarcity situation, such as the oil

47. It appears that the countervailing power argument has appeared persuasive to foreign antitrust officials. For instance, the British Restrictive Practices Court at one time took the view that the existence of a foreign selling cartel justified the creation of a buying group of British manufacturers. In re National Sulphuric Acid Ass'ns Agrecment, L.R. 4 R.P. 169 (Rest. Prac. 1963), aff'd on other grounds, L.R. 6 R.P. 210 (1966). The selling cartel in that case was composed of American sulphur companies operating through a Webb-Pomerene export association. In reaction to the American selling cartel, the British National Sulphuric Acid Association was established as a nonprofit organization for the joint purchase of all the sulphur required by its members for the manufacture of acid. Membership was open to all British manufacturers of sulphuric acid, but resale to persons outside the group was not permitted. 
buying group faced, there may be particularly strong incentives to assure supply through such a deal and pass on the costs to consumers.

In recent testimony, ${ }^{48}$ Assistant Attorney General Kauper declared ineffective for the future the favorable business review clearances which he and his predecessors had granted to the association of oil companies for joint bargaining with the oil producing nations in the period 1971-1973. Kauper suggested that the Antitrust Division had not intended to authorize a permanent cooperative organization of oil companies. He noted that the studies and discussions of the companies' joint bargaining committee ${ }^{49}$ were tending ever closer to sensitive competitive subjects such as estimates of supply and demand and proposals regarding "buy-back" arrangements. He also observed that recent government expropriations of oil property and formation of national oil companies had changed the relationship of the oil companies to the OPEC nations from one of buyer-seller or taxpayer-government to one between actual or potential competitors. Kauper was careful to stress that the Antitrust Division had not yet concluded that any past activity of the oil buying group was violative of the antitrust laws, or that future joint bargaining would necessarily involve any violation. ${ }^{50}$ Nor did he state or imply that business review clearance would be denied in the future to other buying groups. Nevertheless, he did recognize the possible antitrust violations arising out of an international buying group.

\section{B. Foreign Government Cartels}

Whatever the strengths or weaknesses of the countervailing power rationale for allowing joint bargaining with foreign monopolists, it is beginning to appear that other antitrust "exemptions" may be relevant to the joint negotiation issue. Recently, foreign governments in countries with valuable natural resources have sought to increase government revenues from those resources by concertedly demanding higher taxes or royalties for the right of extraction or exportation, or by collectively insisting on some form of "partnership" with American firms. Often, the American buyers have sought to act jointly to protest such a demand or to negotiate about its terms. In this context, there are additional legal bases besides countervailing

48. Statement of Thomas E. Kauper, Ass't Att'y Gen., Antitrust Div., Before the Subcomm. on Multinational Corporations of the Senate Comm. on Foreign Relations, June 5 , 1974 (hearings to be published).

49. This bargaining group was called the "London Policy Group."

50. Statement, supra note 48 . 
power to justify the conclusion that such joint bargaining does not violate American antitrust laws. The Supreme Court has held that the antitrust laws were not designed to prohibit or penalize concerted activity by competitors to obtain favorable governmental action from a legislative or administrative agency. ${ }^{51}$ It remains debatable whether the right to seek to influence governmental action should extend to dealings with foreign governments. ${ }^{52}$ But even assuming there is no quasi-constitutional right to engage in such conduct, one might still conclude that it is beyond the intended coverage of the Sherman Act.

Moreover, the courts have also ruled that antitrust liability cannot be premised upon a competitive effect which is the direct result of a conscious act of state of a foreign government. ${ }^{53}$ The antitrust legality of joint actions abroad depends on the type and extent of the demands made by the foreign governments. The courts have declared that as a general rule, conduct required by foreign law will not be deemed to violate the Sherman Act.54 The law is less clear in regard to conduct which is requested or induced by foreign officials. The Oil Cartel consent decrees seem to recognize foreign government inducement or economic necessity as justifications for engaging in otherwise prohibited acts..$^{55}$

On the other hand, the courts have been unwilling to permit a defense to be based on mere foreign government approval or on foreign government actions which the defendant companies arranged in order to further their own monopolistic scheme. In United States $v$. Sisal Sales Corp. ${ }^{56}$ the indictment alleged that defendants conspired to monopolize sales of sisal (a material used in making rope) from Yucatan, Mexico, to the United States by inducing Mexican officials to recognize the conspirators as the exclusive buyers and sellers of the product and to impose discriminatory taxes on possible rival

51. UMW v. Pennington. 381 U.S. 657 (1965); Eastern R.R. President's Conf. v. Noerr Motor Freight, Inc., 365 U.S. 127 (1961).

52. Occidental Petroleum Corp. v. Buttes Oil \& Gas Co., 331 F. Supp. 92 (C.D. Cal. 1971), aff'd per curiam, 461 F.2d 1261 (9th Cir.), cert. denied, 409 U.S. 950 (1972).

53. American Banana Co. v. United Fruit Co., 213 U.S. 347 (1909); Occidental Petroleum Corp. v. Buttes Gas \& Oil Co., 331 F. Supp. 92, 108-11 (C.D. Cal. 1971); Graziano, Foreign Governmental Compulsion as a Defense in United States Antitrust Law, 7 V.. I. INT't L. 100, 132 (1967). But see United States v. Sisal Sales Corp., 274 U.S. 268 (1927). For a discussion of the act of state doctrine, see Banco Nacional de Cuba v. Sabbatino, 370 U.S. 398 (1964).

54. Continental Ore Co. v. Union Carbide \& Carbon Corp., 370 U.S. 690 (1962) (dicta); United States v. Watchmakers of Switzerland Information Center, Inc., 1963 Trade Cas. 7 70,600 (S.D.N.Y. 1962) (dicta).

55. See United States v. Standard Oil Co. (N.J.), 1969 Trade Cas. I 72,742 (S.D.N.Y. 1968).

56. 274 U.S. 268 (1927). 
sellers. Defendants urged that their alleged actions were immunized against antitrust attack by the act of state doctrine. ${ }^{57}$ The Supreme Court rejected this reasoning, ruling instead that a conspiracy to monopolize formed in the United States for the purpose of securing a monopoly of sales to the United States will not be immunized simply because one element of the conspiracy involved securing favorable action by foreign officials. In the 1962 Continental Ore case the Court indicated that it continued to accept the reasoning of Sisal Sales. 58

It appears that implicit in these Supreme Court decisions is the conclusion that the act of state doctrine does not apply if the foreign government officials were mere pawns in a private conspiracy, rather than a major moving force behind the scheme. It is difficult to infer from the decided cases what the result would have been in a case like Sisal Sales if, for example, the foreign ambassador had sent a note to the Court stating that it was the official policy of the foreign government to select a "chosen instrument" for buying and selling the product in order to create a monopoly and raise the price, thereby increasing the government's tax take. What if the foreign government acknowledged that the idea for the exclusive buyer-seller scheme had come from a group of American companies, but stated that the idea was so good for the country's interest that it was adopted as a matter of national law and policy? Would there then be any recourse under American antitrust law against the companies which urged the scheme on the foreign government? Present law does not provide a definitive answer.

It is with some trepidation that one attempts to apply these nascent and inexact rules to the political and commercial realities of modern joint bargaining. It is certainly conceivable that American companies might be commanded to appear together and bargain jointly with a foreign government monopolist or cartel, or even to cooperate in achieving the restrictive purposes of a producer cartel. It is doubtful that foreign laws would command such conduct. More realistically, the compulsion enforcing such a demand would arise from an express or implied threat by the foreign government to boycott the companies or even to expropriate their foreign holdings. The ques-

57. Id. at 271 (citing American Banana Co. v. United Fruit Co., 213 U.S. 347 (1909)).

58. Continental Ore Co. v. Union Carbide \& Carbon Corp., 370 U.S. 690, 705 (1962). (Canada made a subsidiary of defendant an exclusive agent for importation of certain substances. "As in Sisal, the conspiracy was laid in the United States, was effectuated both here and abroad, and respondents are not insulated by the fact that their conspiracy involved some acts by the agent of a foreign government.") 
tion then is whether the United States should accord such economic pressure the legal status of an antitrust defense if it sees the foreigners' scheme as being against its interest as a consumer nation. If the American companies are called together merely to facilitate the uniform and prompt resolution of an economic dispute, American antitrust forbearance seems appropriate. But if the companies are pressured to cooperate in a scheme to exact higher prices from American consumers, it would seem well within the discretion of American courts to afford no weight or legitimacy to the foreign inducement and to compel the companies to obey American law even at the cost of alienating their foreign sources of supply. ${ }^{89}$

\section{Acceptable Conduct by Bargaining Groups}

We have seen that there is an arguable, though highly debatable, case for sometimes permitting or even assisting international buying groups as a countervailing force to foreign cartels, and for holding that joint activities in relation to foreign taxation or participation programs are outside the intended coverage of the Sherman Act. Nevertheless, even assuming these premises, American antitrust law will still be relevant to the manner in which the buying group is organized and joint bargaining is conducted.

The first issue here centers on admission to such buying groups. There is a considerable body of American case law, from United States v. Terminal Railroad Association, ${ }^{60}$ through Associated Press v. United States, ${ }^{61}$ to Silver $v$. New York Stock Exchange, ${ }^{82}$ holding that businessmen who jointly control a crucial economic facility must make entrance to the group available on reasonable, nondiscriminatory terms to all whose ability to compete would be seriously impaired by exclusion. It would thus follow that a syndicate for dealing with a foreign monopolist or cartel would be legal only if member-

59. Cf. First Nat'l City Bank v. IRS, 271 F.2d 616 (2d Cir. 1959), cert. denied, 316 U.S. 948 (1960) (dictum) (corporation may have to obey U.S. court order even at risk of losing right to do business in a foreign state; "If the Bank cannot, as it were, serve two masters and comply with the lawful requirements both of the United States and of Panama, perhaps it should surrender to one sovereign or the other the privileges re. ceived therefrom."); Bernstein v. N.V. Nederlandsche-Amerikaansche Stoomvaart-Maatschappij, 210 F.2d 375 (2d Gir. 1954) (plaintiff may challenge validity of Nazi acts of state).

60. 224 U.S. 383 (1912) (an association of railroads sharing certain tracks tried unsuccessfully to deny admission to certain other railroads).

61. 326 U.S. 1 (1945) (all newspapers must be allowed to use Associated Press facilities).

62. 373 U.S. 341 (1962) (all brokers must be allowed to use stock exchange). 
ship in it is open on reasonable terms to all who have a competitive need to participate. ${ }^{.3}$ Similarly, serious antitrust questions would arise if American firms, in dealing with foreigners controlling a scarce resource, agreed to higher prices in exchange for exclusive rights and thus prejudiced other American firms excluded from the buying group.

Given that a buying group open to all appropriate members may not be illegal in itself when necessary to confront a foreign cartel or government, the next issue concerns the range of acceptable tactics that the group may employ. An important question is the extent to which the majority of the group may impose its will on dissidents. Certainly the visceral reaction of most antitrust enforcers, as well as most Americans, would be that the group should have no power or right to coerce uniformity among its members. Yet the issue is not quite as simple as it appears. May the members agree to be bound by a majority vote in bargaining positions? If so, then it is clear that a company may be compelled by the votes of its competitors to take an economic position it would not have adopted if acting alone. Suppose the old price is $\$ 4$, the foreign cartel asks for an increase to $\$ 6$, the buying group decides to offer $\$ 5$, and after three days of deadlock one American firm decides it would like to agree to the $\$ 6$ price. May the other members of the buying group attempt to persuade the dissident to hold out a bit longer? Should any limits be placed on the nature or the vigor of the persuasion? Existing antitrust law seems generally to indicate that if such conduct amounted to coercion, it would be illegal. In Georgia v. Pennsylvania Railroad Co., ${ }^{64}$ the Supreme Court, in considering the legality of an alleged railroad conspiracy which required uniform adherence to discriminatory rates, stated:

63. In considering discrimination by buying groups, FTC Chairman Dixon stated: After considerable study of the problem, we decided the way to eliminate the discrimination-hence the competitive injury-was not to condemn the buying group but to open its doors to every other jobber who competes with one or more of the group's members, to assure their competitors an equal opportunity to perform the same services or "functions" for the manufacturer and be paid on the same basis. The groups that are willing to do this-those that are willing to positively and affirmatively invite all competing jobbers to join and receive the same low prices as their existing members, to eliminate the discrimination, to eliminate the competitive injury, to eliminate the receipt of payment for services and functions they don't perform-are thus converting themselves into genuine, bona fide "cooperatives." The others-those that insist on maintaining a closed, exclusive club, on receiving not just a low price but a discriminatory price advantage over their competitorsare showing their true colors, too. They aren't "small businessmen" seeking an equally low price; they're powerful buyers demanding lower prices, prices that give them a grossly unfair advantage over decidedly smaller firms than themselves.

Quoted in Mezines, Group Buying, 12 ANritrust BuLL. 535, 553-54 (1967).

64. 324 U.S. 439 (1945). 
[W] find no warrant in the Interstate Commerce Act and the Sherman Act for saying that the authority to fix joint through rates clothes with legality a conspiracy to discriminate against a State or a region, to use coercion in the fixing of rates, or to put in the hands of a combination of carriers a veto power over rates proposed by a single carrier. The type of regulation which Congress chose did not eliminate the emphasis on competition and individual freedom of action in ratemaking. ${ }^{65}$

The tendency of American public policy in this regard is illustrated by the fact that when Congress adopted the Reed-Bulwinkle Act ${ }^{66}$ to legalize joint rate-fixing by railroads, it stated expressly that such agreements could be approved by the ICC only if each party to the agreement retains a "free and unrestrained right to take independent action either before or after any determination arrived at through such procedure." 67 Bargaining groups which seek to prevent independent action by members may therefore violate the antitrust laws.

Another difficult question about permissible tactics is whether the members of a buying group may agree to joint action if their bargaining reaches impasse. Using the facts of the previous hypothetical, if the foreign cartel sticks to its demand for a $\$ 6$ price and the American buyers hold fast to their $\$ 5$ offer, may the Americans jointly agree to withhold $\$ 1$ when the price is demanded? If the foreigners will not sell unless the $\$ 6$ price is paid, may the American firms agree not to buy any of the commodity, that is, to boycott the foreigners? At an extreme, may they agree to boycott the foreigners as to other products in order to exert leverage to reduce the price of the first product? The obvious answer would seem to be that when American companies jointly decline to purchase a commodity normally consumed in this country, they are collusively restraining the import trade of the United States and thus violating its antitrust laws. If buying groups are permitted to bargain jointly with the foreigners because of the existence of a cartel or monopoly, and if obtaining a low price is important to consumers, to the balance of payments and perhaps to other national interests, it may arguably be illogical to deny them the leverage that a boycott might create. Nevertheless, I think that, absent direct American government involvement in the boycott, it is reasonable and desirable to ban such tactics, even against a foreign cartel. First, there seems to be no basis

65. Id. at 458.59 (emphasis added).

66. 49 U.S.C. $\& 5(b)(1970)$.

67. Id. $\S 5(\mathrm{~b})(6)$. 
at all in previous antitrust doctrine for excusing such a boycott that denies products to American consumers. ${ }^{68}$ In addition, the absence of government control of the resale prices and profits of the bargaining firms means that there is no assurance that the lower purchase price the boycott is intended to induce will benefit the public. Finally, it must also be remembered that foreign trade and foreign relations are not "zero-sum games" in which there is simply a winner and a loser. ${ }^{.9}$ Using power tactics to exact a concession, perhaps from a developing country seeking to exploit one of its few valuable resources, may be against the long run foreign policy interests of the United States even if it fends off an unwelcome price increase for a while. It may be even worse policy if employed against a powerful state which has at its disposal numerous means of economic and diplomatic retaliation. ${ }^{70}$

\section{The Role of Government in Joint Bargaining}

One of the most difficult issues arising from joint international bargaining by firms with combined monopoly power is what role the United States Government should play. If the particular commodity is important, should the Government have the power to require the bargaining firms to refuse to pay the price demanded by the foreign government or cartel? At the other extreme, should the Government

68. For the rule that the Sherman Act prohibits boycotts, see Associated Press v. United States, 326 U.S. 1 (1945); Klor's Inc. v. Broadway Hale Stores, Inc., 359 U.S. 207 (1959). This prohibition of boycotts extends to foreign commerce. United States v. Hamburg-American S.S. Line, 200 F. 806 (S.D.N.Y. 1911), 216 F. 971 (S.D.N.Y. 1914), rev'd on other grounds, 239 U.S. 466 (1916); United States v. Pacific \& Arctic Ry. \& Nav. Co., 228 U.S. 87 (1913). See also United States v. Diamond Dealers Club, Inc., 1952 Trade Rec. REP. If 66,036 (criminal), 66,042 (civil) (S.D.N.Y. 1952) (government attacked an agreement among U.S. diamond dealers and Belgium association to boycott the diamond industry of Germany; defendants entered nolo contendere pleas in the criminal action; the civil case was settled by consent judgment). A more recent case is United States $r$. American Soc'y of Mechanical Engineers, Inc., Civil No. 1807-M (D. Mass., July 22, 1970) (government challenged a conspiracy against foreign manufacturers of boilers and pressure vessels), 1972 Trade Cas. 74,028 (S.D.N.Y. 1972) (consent settlement).

69. See T. Schelling, The Strutegy of CoNflict (1962).

70. This discussion does not imply that there would be no benefit or utility in form. ing a buying group. Provided that there is neither coercion of members nor a collective boycott, those in the group could agree to reject an offer by the foreign seller, or even to terminate the negotiations. The possibility of such action would be important in the bargaining process if, for example, the seller wished to legitimate his position by obtaining the collective assent of the buyers, or if cooperation among the buyers was vital in implementing the new terms or conditions of sale. Of course, if an offer were rejected or the negotiations terminated by the buying group, the Sherman Act would prohibit any subsequent agreement not to buy or import the product. However, uniformity among the group members in refusing to deal with an unreasonable foreign seller would not in itself prove the existence of an illegal course of concerted. conduct. Theatre Enterprises, Inc. v. Paramount Film Distrib. Corp., 346 U.S. 537 (1959); Milgram v. Loew's, Inc., 192 F.2d 579, 583 (3d Cir. 1951), cert. denied, 343 U.S. 929 (1952). 
be able to compel them to pay the price rather than have negotiations break down? Should the Government even suggest how the firms should bargain? If orders or suggestions are thought vital to the national interest, what is the legal authority for such an active governmental role in foreign trade? ${ }^{71}$ True, the antitrust laws provide a basis for enunciating some of the rules for conducting joint negotiations, but they can hardly be used as authorization or guidance for active government superintendence of how to bid or how much to pay.

Present United States law does not authorize, or even provide policy objectives to justify, the participation by government officials in the formulation or tactical implementation of bargaining strategies of American corporations dealing with foreign monopolies or cartels. Certainly, American officials know that national policy generally favors friendship with other nations, a "favorable" balance of trade, low prices for consumer goods and an assured supply of strategic commodities. But these objectives are quite general and can obviously be contradictory in the context of a particular negotiation.

In some other nations the government is an owner or stockholder in that country's major international companies, and thus has a clear legal right to influence the decisions of such companies. Some countries require that particular types of foreign trade be conducted only by state trading organizations. This provides the most direct form of state control over international bargaining for commodities thought vital to the nation's interest. At least until now, America has always rejected these approaches, relying instead on our antitrust laws, on corporate strength, self-interest and statesmanship, and on informal diplomatic persuasion of foreign governments and American multinational corporations. However, as has been discussed, our antitrust laws probably do not provide a solution in themselves.

Using governmental recommendations to "guide" the behavior and bargaining of our multinational corporations may be effective on occasion, but it is obviously an uncertain procedure; a corporate executive is obviously free under our system to take the position that he will not prejudice the profit interests of his stockholders in order

71. In Senate hearings related to the oil cartel, Senator Church suggested to Federal Energy Administrator John Sawhill that legislation should be passed requiring the submission to the FEA of all major international oil agreements by American companies and setting forth standards under which FEA would approve or reject such contracts. Sawhill agreed that such legislation would be desirable. A bill approved by a Senate Foreign Relations subcommittee requires the Federal Energy Administrator to approve all long term contracts between American companies and foreign governments. BNA 1974 ANtitrust \& Trade Reg. REp. No. 680, at A-16. It is difficult to estimate the likelihood that such a bill would be adopted by the Congress. See note 9 supra. 
to comply with the suggestion of a government official that a less profitable course would be better for foreign relations, the balance of payments, national defense, or the like. Yet, if the company follows the suggestion as a favor to the Government, the implication may arise that the Government then "owes" the company a reciprocal favor, perhaps in the form of lenient law enforcement. Confidence in the primacy of the rule of law in our nation requires that the relation between profitmaking corporations and government should be at arm's length, governed by statutorily determined rights, obligations or incentives, not by bureaucratic requests for corporate favors. In antitrust law this principle has been expressed in the longstanding doctrine that conduct violative of the Sherman Act will not be excused because it was done with the knowledge, approval or even encouragement of government officials. ${ }^{2}$ On the other hand, corporate conduct directly induced or compelled by government officials in order to achieve the purpose of a statute designed to provide a substitute for normal free market forces normally will not be held illegal under the antitrust laws. ${ }^{73}$

These issues are highlighted by the so-called "voluntary" steel import quotas. ${ }^{74}$ "The facts appear to be that in 1969, under pressure from House and Senate Committees threatening legislative import quotas to protect the domestic steel industry from foreign competition, and after negotiations with State Department officials, the major Japanese and European steel manufacturers agreed to work out cooperative plans under which they would limit the amount of their exports to the United States for a three-year period. Both the European and the Japanese producers announced their agreement to the plan in letters which stated that it was their understanding that the plan would not violate the laws of the United States. Nevertheless, a number of prominent American lawyers questioned whether the agreements were legal under our antitrust laws. ${ }^{75}$ This arrangement was challenged by Consumers Union in 1972, but the parties agreed to a dismissal with prejudice of the antitrust allegations in the complaint. $^{78}$

72. Continental Ore Co. v. Union Carbide \& Carbon Corp., 370 U.S. 690, 705 (1962);

United States v. Socony-Vacuum Oil Co. 310 U.S. 150 (1940).

73. See, e.g., Parker v. Brown, 317 U.S. 341 (1943).

74. See Note, Cartelization, Executive Sanction, and the Antitrust Laws: The Steel Import Case, 18 Antitrust Buld. 853 (1973).

75. See Symposium, Antitrust Enforcement in the Atlantic Community, 40 AntrTust L.J. 761, 796, 801.04 (1971) (comments of Rahl, Maw \& Fugate).

76. Consumers Union, Inc. v. Kissinger, Civil No. 73-1095 (D.C. Cir., Oct. 11, 1974), aff'g as modified 352 F. Supp. 1319 (D.D.C. 1973). Notwithstanding the dismissal, U.S. District Judge Gerhard A. Gesell expressed his view that the agreement was not lawful 
The Defense Production Act of $1950^{77}$ should also be noted here. Although unused against buying groups and little discussed in the literature, this statute would both allow the government to play a substantial role in foreign trade and enable businessmen to secure a complete antitrust exemption to exert concerted buying power against foreigners. In broad summary, the Act provides that in the event of world conditions threatening the supply to the United States of a commodity important to national defense, the Secretary of the Interior may declare that an emergency exists. ${ }^{78} \mathrm{~A}$ special governmentindustry advisory group may then be established to discuss problems of supply and possible solutions. ${ }^{79} \mathrm{~A}$ plan of action may then be drafted and submitted to the Attorney General for approval and to the Chairman of the FTC for review. Once the plan is approved, anything done under it is declared by $\S 708$ of the Act to be fully exempted from the operation of the antitrust laws. ${ }^{80}$

Most average international trade situations and strategies would not fall within the intended purview of the Defense Production Act. However, if a foreign monopoly, cartel or boycott did threaten the ability of American firms to obtain a crucial commodity, the Act provides a means by which, with the consent or advice of the Department

under Parker v. Brown, 317 U.S. 341 (1943) (agreement induced by public officials for a public purpose are immune under the antitrust laws). He stated that "the Executive has no authority under the Constitution or acts of Congress to exempt the Voluntary Restraint Arrangements on Steel from the antitrust laws and that such arrangements are not exempt." 352 F. Supp. at 1323. Although Judge Gesell did not explain his reasoning in detail, he apparently believed that an implied exemption would be appropriate only if the State Department officials had acted under a statute specifically authorizing them to negotiate with private corporations for restraints on American foreign commerce. On appeal, the Court of Appeals for the District of Columbia ruled that negotiating voluntary agreements was within the President's authority. The majority vacated the antitrust discussion in the district court and refused to consider whether the President's actions created antitrust immunity for the private parties, noting that Gesell's statement was dictum and that the Justice Department had stated to the district court that no participant was assured of antitrust immunity. In dissent, Judge Leventhal argued that the executive actions were ultra vires and that no antitrust immunity or exemption should result from them; however, he concluded that the ruling should be prospective only, so that the parties would not be liable for treble damages.

77. 50 U.S.C. App. $\$ \S 2061-2166$ (1970).

78. Id. $\$ 2093(\mathrm{~g})$.

79. Id. $\$ 2158(\mathrm{a})$.

80. Pursuant to $\S 708(e)$ of the Defense Production Act of 1950 , id. $\$ 2158(e)$, the Attorney General is directed to review the administration of that Act to determine any factor which may tend to eliminate competition, create or strengthen monopolies, injure small business, or otherwise promote undue concentration of economic power. The 1955 amendments to the Defense Production Act, Act of Aug. 9, 1955, ch. 655, $\$ 6$, 69 Stat. 581, require the Attorney General to issue reports on these matters every three months, and to include in those reports a review of all voluntary agreements approved under $\S 708$. Such reports have been regularly submitted. See generally Review of Voluntary Agreements Program under the Defense Production Act, Reports submitted by the Att'y Gen. to the Senate Comm. on Banking and Currency (1956-1974). 
of the Interior, the Justice Department and the FTC, the affected companies could form virtually any kind of counter-cartel without fear of antitrust sanctions.

\section{Conclusion}

This article began with the inquiry whether United States antitrust laws unduly hamper our businessmen in international trading. In my view, analysis of our antitrust laws as applied and interpreted reveals that they are not an undue hindrance to necessary or even useful forms of cooperation in international buying. Cooperation to achieve cost savings and efficiencies among small companies lacking market power is undoubtedly legal, as can be deduced from the application of antitrust laws to domestic buying groups. Those types of joint group activities which the antitrust laws do prohibit are ones which are likely to injure competitive businesses in America and to interfere with American foreign relations. We have also seen that the antitrust laws have not yet been applied to prohibit American firms from bargaining jointly with a foreign government or cartel. However, even if bargaining groups are permissible, it does appear that the law should and would be applied to guarantee appropriate access to these groups, to limit somewhat the methods and tactics which may be employed, and perhaps to prevent "sweetheart deals" with foreign cartels. Finally, given the justifiable American suspicion of unchecked private power, it would seem far preferable that any such counter-cartels be composed of, or closely supervised by, the affected consumer governments themselves.

All this is not to say that the conduct of international trading as a contest between rival buying and selling cartels is in any sense a desirable development. Economists and statesmen have pointed out that although cartels may gain short term advantages by distorting the factors which influence supply, demand and price, such conduct in the long run will not only engender retaliation but will also cause a frantic search for substitute products and alternative markets, which may well erode whatever gains the concerted activity initially achieved. ${ }^{81}$ Cer-

81. "Experience suggests that cartels are difficult to organize and more difficult to execute. They require effective control over supply. Producers can be induced to export in excess of the quota if additional sales offer the immediate prospect of additional earnings to each. Even assuming a degree of discipline and unanimity among producing countries than past experience suggests is unlikely, success would probably be short-lived. The stimulus to production, the shift to substitutes, the encouragement to new tech- 
tainly, an American governmental policy designed to impress free market principles upon those foreign businesses that seek monopoly selling or buying power would be better than a policy of increasingly permissive antitrust interpretation or legislation designed to facilitate creation of American counter-cartels. Experience teaches us that once created, such cartels are extremely difficult to guide, to control and to eliminate. Moreover, counter-cartels may help to buttress or stabilize a producer cartel that would otherwise splinter and disintegrate. ${ }^{82}$ Therefore, we must now hold fast to the fundamental principles of competition embodied in our laws, before they are irretrievably washed away in the treacherous currents of international economic crises.

nologies that economize on use and consumer resistance are likely to leave producers in due course in a worse position than before, with markets irreversibly lost." Statement of Thomas O. Enders, Ass't Sec'y of State for Economic and Business Affairs, Before the Economic Growth Subcomm. of the Jt. Economic Comm., July 25, 1974 (hearings to be published).

82. "In the petroleum market, corporate behavior has facilitated collusion among exporting countries. The oil companies have willingly participated in a tax structure that discourages competitive behavior, have regulated output themselves, have created an artificial pricing system, and have capitulated in demands for price increases." Krasner, supra note 2 , at 77. 


\section{The Yale Law Journal}

Volume 84, Number 2, December 1974

\author{
David A. Martin \\ Editor-in-Chief \\ W. Duane Benton \\ Managing Editor \\ R. Hale Andrews, JR. \\ PhILIP C. BobbitT \\ LAURa J. CoRWIN \\ Alan B. LoughnaN \\ Article \& Book Review \\ Editors
}

\author{
MARK I. Levy \\ Executive Editor
}

ANDREw H. COHN

Note ir Project Editor

Holly E. Kendig

Charles H. Montange

STEPHEN R. MYSLIWIEC

Lewis T. Stevens

JOHN P. WHEELER III

Note Editors
Paul G. Abramis

Samuel A. Alito

Ned T. AsHBY

RoY L. Brooks

Sanford B. Ferguson

William A. Fletcher

Thomas H. Jackson
ANTHONY T. KRONMAN

Richard B. LeVIN

WALTER P. LOUghlin

OWen E. MacBride

Elliot E. Maxiwell

Charles A. Patrizia

Jan-Anders Paulsson
George K. Rahdert JefFrey L. Schulte Mary A. Siegel ROBERT M. SMITH JoHN W. SPIEgel Michael L. TabaK EdWARd A. ZeLinsky

Secretaries to the Editors M. Olive Butterfield, Pamela Willmott

\section{Student Contributors to This Issue}

Michael L. Tabak, Federal Compensation for Victims of the "Homeownership for the Poor" Program

George K. Rahdert, Discounted Preferred Stock under the New Section 305 Treasury Regulations: On Confusing Debt and Equity

Jeffrey L. Schulte, Area Search Warrants in Border Zones: Almeida-Sanchez and Camara 